\title{
A Economia Solidária diante das Desigualdades*
}

\author{
Hans Benno Asseburg \\ Luiz Inácio Gaiger
}

$\mathrm{U}$

ma das graves conseqüências das disparidades sociais que o Brasil ostenta é o seu nível superlativo de pobreza, decorrente da desigual apropriação e repartição da riqueza, em contraste com a abundância de recursos e com a capacidade produtiva do país. A persistência das desigualdades ao longo de nossa história indica que as mesmas possuem raízes profundas, ante as quais políticas de crescimento econômico e medidas compensatórias dirigidas à população de baixa renda não têm surtido efeitos decisivos e prolongados. Outrossim, a queda da desigualdade registrada após 2001, somada ao debate e às tentativas recentes de remodelagem das políticas públicas, diante de um quadro social agravado e quase em descontrole, justifica que se contemplem e explorem novas alternativas, sobretudo quando favoráveis ao desenvolvimento social e produtivo dos trabalhadores pobres, de modo que possam gerar renda por sua própria conta e conquistar níveis mínimos de autodeterminação.

A tese examinada neste artigo diz respeito à contribuição da economia solidária nesse sentido, uma vez que suas organizações, ao se valerem

\footnotetext{
*Este artigo resulta de estudos do Grupo de Pesquisa em Economia Solidária, vinculado ao Programa de Pós-Graduação em Ciências Sociais da Universidade do Vale do Rio dos Sinos - Unisinos, com apoio do Conselho Nacional de Desenvolvimento Científico e Tecnológico - CNPq, da Fundação de Amparo à Pesquisa do Estado do Rio Grande do Sul FAPERGS e da Organização das Nações Unidas para a Educação, a Ciência e a Cultura Unesco.
}

DADOS - Revista de Ciências Sociais, Rio de Janeiro, Vol. 50, nº3, 2007, pp. 499 a 533. 
da cooperação produtiva e acionarem circuitos de reciprocidade, tendem a exercer efeitos diretos na distribuição dos resultados, no fortalecimento dos seus membros e na promoção da eqüidade. Alguns estudos chegaram há bastante tempo a conclusões dessa ordem: ao efetuar um balanço das conquistas dos pequenos projetos comunitários no Estado da Bahia, Oliveira (1988) já destacava a redução do nível de empobrecimento, que atenua o grau de penúria e aumenta as chances de permanência das pessoas em seus locais de origem. Os recursos gerados por tais projetos, segundo o autor, fluíam igualmente para a comunidade, que assim conseguia minorar sua dependência das ajudas convencionais. Ao mesmo tempo, essas iniciativas gerariam um novo entendimento da vida social e uma postura crítica diante das relações de poder.

Nos dias atuais, a presença de múltiplas iniciativas de associação voluntária de trabalhadores, mediante partilha dos recursos produtivos, cooperação no trabalho e gestão coletiva, cuja expansão gradativa desde os anos 1980 veio a produzir o movimento social da economia solidária, confere visibilidade a esse campo ${ }^{1}$ e o converte em objeto de estudo digno de interesse. Entre outros aspectos, cabe averiguar em que medida os empreendimentos de economia solidária e seus dispositivos de articulação representam bases adequadas à constituição de nova matriz e à formulação de um novo modelo de desenvolvimento. Este artigo procura fazê-lo a partir de um ângulo de análise centrado na dinâmica e nos efeitos sociais gerados pelos empreendimentos de economia solidária, em razão de sua adesão a princípios e regras igualitaristas, decorrentes de sua natureza coletiva e de sua índole socializante.

O texto discute inicialmente as raízes e a natureza multidimensional das desigualdades, posicionando-se a seguir diante do debate controverso sobre as suas vias de superação e de redução da pobreza. A abordagem dessas questões gerais servirá, na seção seguinte, à apresentação mais clara e com a devida pertinência da questão proposta para análise, apoiada em argumentos a favor de estratégias que privilegiam a ativação da capacidade individual e coletiva dos atores econômicos relegados à pobreza. Na seqüência do texto, caracteriza-se a metodologia da pesquisa à origem dos dados examinados para o tratamento empírico da questão em tela. Nas seções seguintes, o estudo de um conjunto de indicadores conduzirá a um balanço gradativo dos pontos fortes e dos limites dos empreendimentos de economia solidária. Ao final, 
a consideração de outros estudos sobre o tema trará elementos adicionais acerca do sentido primordial das experiências de economia solidária, para a vida dos trabalhadores empobrecidos e para a promoção da eqüidade.

\section{FACES E PERSISTÊNCIAS DAS DESIGUALDADES}

As desigualdades no Brasil possuem raízes profundas, que remontam à formação da sociedade escravocrata e à instauração da cultura política da dádiva e da subseqüente dívida moral dos escravos e homens pobres para com os mandatários e senhores de terras. Tal cultura de mando e subserviência, transcendendo ao domínio privado das fazendas e engenhos, sobreviveu à abolição da escravatura, reapareceu na ordem coronelista e chegou aos nossos dias, subtraindo os direitos básicos da cidadania enquanto se oculta atrás do fetiche do encurtamento das distâncias sociais (Sales, 1994). Uma das conseqüências políticas desta outorga histórica de direitos foi o trato privado da coisa pública, que explica nossa impossibilidade de romper com os padrões particularistas que entravam e subvertem a gestão do interesse público. A privatização das relações sociais opôs-se ademais ao reconhecimento e à legitimação das singularidades e diferenças. Camuflada, a intolerância à alteridade foi igualmente um vetor poderoso das desigualdades, profundamente internalizadas no imaginário nacional. Pode-se dizer, em suma, que as estruturas e os processos definidores de nossa formação histórica, ao instituírem uma dinâmica permanente de produção-resistência-mudança-reprodução das desigualdades, não apenas caracterizam a questão social no Brasil, mas constituem o seu elemento determinante.

A pobreza extrema, problema crucial adiante abordado, não está localizada na insuficiente produção econômica, mas em sua má distribuição (Medeiros, 2005). Ela reside nos processos de reiteração das desigualdades que explicam por que, ao cabo de sucessivas fases de estagnação e de crescimento, o Brasil deixou de ser um país pobre e dependente, para converter-se em uma das principais economias mundiais (12a em 2004), sem deixar de conviver com um dos mais baixos índices de desenvolvimento humano - IDHs. Transcorrida em tais termos, nossa história justifica a errância do homem pobre brasileiro, como via inglória de escape, a desenhar a geografia e a paisagem social do país. Desde suas origens, privação, submissão e esquecimento andam jun- 
tos em nossa formação social, a retratar as múltiplas faces das desigualdades.

A inegável evolução do direito positivo das últimas décadas e a remoção de entraves formais, de par com as políticas de assistência, empregabilidade e inclusão, tampouco lograram afetar drasticamente as desigualdades. Elas resistiram aos movimentos e às pressões sociais, reproduzindo divisões, separações e enormes desproporções no acesso de uns e outros aos bens materiais e imateriais gerados pela socieda$\mathrm{de}^{2}$, e persistiram ainda no plano dos valores: malgrado os avanços notórios na abordagem das diferenças geracionais, de gênero e outras, as desigualdades restam incorporadas aos padrões e hábitos culturais e seu poder instituinte aparece nas formas latentes de segregação, a demonstrarem a força inercial de atavismos há muito banidos do quadro de direitos, ou na naturalidade com que se aceita a brutal distância social entre os brasileiros.

Daí porque certas desigualdades no Brasil possuem um claro vetor cultural, a exemplo da participação inferiorizada das mulheres no mercado de trabalho quanto aos índices de emprego, de ascensão profissional e de remuneração. $\mathrm{O}$ mesmo vale para a população não-branca, a quem dados dos anos 1990 (Dieese, 2002) mostram ser ainda destinada às funções mais desgastantes, aos empregos mais vulneráveis e aos salários mais modestos ${ }^{3}$. Quando se contabilizam fatores de ordem cultural dotados de algum grau de racionalidade, como os níveis de escolarização, o resultado é sombrio: a exclusão econômica dos pais gera a exclusão escolar e, a seguir, a exclusão social e econômica dos filhos, o que explica que pardos e negros sigam sem capital e com minguadas chances de acumulá-lo (Singer, 1999:100) ${ }^{4}$. Ainda que sua condição escolar atualmente experimente alguma melhora, terão que se haver com o fato de que a educação é um agravante, mas não o fator decisivo na produção das desigualdades de renda. Estas repousam antes no papel desempenhado pela estrutura de remuneração do mercado de trabalho, na riqueza herdada e nos recursos de capital e de poder há mais tempo cativos das classes possuidoras de riqueza (idem; Medeiros, 2005).

As desigualdades econômicas, políticas e culturais formam um círculo perverso, cujo cerne se mantém inabalado e parece recrudescer quando políticas sociais e medidas redistributivas fazem cair os seus índices passageiramente. Mesmo nas fases de crescimento econômico e de 
evolução dos indicadores sociais, as tendências de repartição desigual da renda e de acesso diferenciado aos serviços e garantias sociais mantiveram-se constantes, pouco sensíveis ao desempenho da economia e ao acionamento de políticas compensatórias. Assim, o Milagre Brasileiro, última fase de crescimento contínuo, teve sua eficácia em reduzir os níveis de pobreza rapidamente compensada ao longo e ao final dos anos 1980, com a volta aos índices anteriores. Já em 1983, “a incidência de pobreza retornou ao nível de 1960, enquanto o PIB per capita era ainda quase o dobro do nível daquele ano" (Singer, 1999:92-93). Entre 1976 e 1990, a estabilidade do coeficiente de Gini evidencia que a desigualdade permaneceu estável, indiferente à evolução da economia, da política e dos costumes, "apesar de o Brasil ter-se aproximado de maneira crescente da maior parte das características atribuídas às sociedades modernas que têm patamares de desigualdade menores" (Medeiros, 2005:47). Dada a desestruturação do mercado de trabalho advinda a partir de 1980 (Pochmann, 2001), tais distâncias alargaram-se ao menos até a década seguinte, com o incremento do desemprego aberto e a diminuição relativa do emprego industrial, majoritariamente formalizado, em contrapartida à expansão dos empregos mais desprotegidos, típicos das prestações domésticas e do setor de serviços.

A desigualdade econômica brasileira permaneceu estável e elevada entre 1970 e 2000 (Neri, 2007). Assim, ao final dos anos 1990, a sociedade mostrava-se segmentada em dois grupos distintos: "uma massa homogênea, formada por uma população de baixa renda e uma pequena, porém rica, elite" (Medeiros, 2005:249). Uma renda tão concentrada que a soma de rendimentos da metade mais pobre era inferior àquela percebida pelo centésimo mais rico. Os $5 \%$ mais ricos detinham um terço do total de rendimentos, e os 10\% mais ricos, cerca de $50 \%$ dos mesmos. As sobreposições entre as elites econômicas, políticas e sociais, aliadas ao fato de que a riqueza provém em boa medida de relações com o Estado, como efeito de suas políticas macroeconômicas e de políticas sociais sem eficácia distributiva, permitem ademais que a desigualdade de renda no país possa ser considerada um indicador de outros tipos de desigualdade (idem).

Durante a presente década, a desigualdade apresentou inflexões positivas, embora sem um desfecho seguro e claramente animador. No Rio Grande do Sul, esses sinais já aparecem ao se compararem os dados do período de 1981 a 2002. Por um lado, o índice de Gini de 1981, de 0,5443, é praticamente igual ao de 2002, de 0,5479, embora tenham ocorrido os- 
cilações, em efeito breve do Plano Cruzado e um pouco mais longo do Plano Real. A distribuição de renda, segundo os dados da Pesquisa Nacional por Amostra de Domicílios - PNAD, sofreu poucas alterações, no sentido da concentração: os 10\% mais pobres da população gaúcha detinham 1,10\% da renda em 1981, cabendo-lhes 1,02\% da renda em 2002; os $10 \%$ mais ricos, a quem cabiam $43,16 \%$ da renda em 1981, ficaram com $43,45 \%$ da renda em 2002. Por outro lado, as proporções de pobres e de indigentes caíram, respectivamente, de 30,75\% para $21,52 \%$ e de $10,38 \%$ para $6,89 \%$. Houve uma queda moderada da pobreza: a década de 1980 foi desfavorável aos pobres, ao passo que a de 1990 propiciou uma lenta e modesta elevação de sua renda (Picolotto, 2005).

O declínio da desigualdade no país durante os anos 2000 é expresso principalmente pela queda no coeficiente de Gini, que oscilou $4,6 \%$ entre 2001 e 2005, passando de 0,594 para 0,566. A queda da desigualdade relaciona-se ao crescimento da renda dos mais pobres, cuja fatia da renda nacional ficou bem acima das faixas de mais altos rendimentos. $\mathrm{O}$ incremento da renda per capita dos $10 \%$ mais pobres atingiu $8 \%$ ao ano, quase nove vezes o crescimento da renda nacional, 90\% desse incremento estando associado à redução das desigualdades. Por sua vez, a renda per capita dos $20 \%$ mais pobres cresceu $6 \%$ ao ano, $85 \%$ dos quais explicáveis pela queda das desigualdades, isto é, por menor elevação ou decréscimo da fatia reservada aos segmentos superiores (Barros et alii, 2007:333). Assim, a proporção de pobres e de extremamente pobres experimentou significativos descensos. Entretanto, o país segue em posição claramente negativa no cenário internacional, não obstante avanços simultâneos em índices como o acesso à educação e a expectativa de vida da população, que resultaram em melhoras no IDH (Cohn, 2003). Seriam necessários ainda mais de 20 anos para o Brasil atingir um nível similar ao da média dos países com maior grau de desenvolvimento. Caso a queda na pobreza contasse apenas com o fator crescimento, seriam necessários incrementos do Produto Interno Bruto - PIB superlativos e ganhos na renda de todas as famílias em níveis muito superiores aos das últimas décadas, expectativas sem dúvida muito improváveis (Medeiros, 2005).

Dados de 2006, apurados com base na Pesquisa Mensal de Emprego PME, sinalizam que o declínio das desigualdades estaria perdendo força: o índice de Gini nas seis regiões metropolitanas pesquisadas pela PME estabilizou-se nesse ano, sem avanços na desconcentração da renda do trabalho. De julho de 2005 a junho de 2006, a taxa de misé- 
ria sofre um tênue movimento de ascenso, de $0,29 \%$, contra uma queda de 12,28\% registrada nos 12 meses anteriores. Ao mesmo tempo, aparecem evidências de perda de quantidade e de qualidade do emprego, compensando negativamente os aumentos reais do salário mínimo em 2005 e 2006. Ao contrário dos anos anteriores, o período de julho/2004 a junho/2006 é "apenas ligeiramente pró-pobre e antielite" (Neri, 2007:214).

\section{O PAPEL INDISPENSÁVEL DAS POLIITICAS DISTRIBUTIVAS}

Os vetores estruturais de reprodução das desigualdades jazem na repartição histórica do patrimônio e dos bens produtivos, garantem-se por meio da extração do excedente do trabalho pelo capital no interior do processo de produção, ampliam-se com as discrepâncias de remuneração do trabalho e completam-se na alocação regressiva das frações do excedente recolhidas pelo Estado. No Brasil, desigualdade e pobreza são fenômenos associados. Das controvérsias sobre sua resolução, principalmente quanto à eficácia das políticas direcionadas ao crescimento da economia, quando expostas à avaliação histórica dos fatos, pode-se extrair a seguinte linha de argumentação:

Primeiramente, desigualdade não gera crescimento econômico nem este, posteriormente, produz por si mesmo diminuição da desigualdade e nivelamentos da renda. Contrariamente ao apregoado pela ciência econômica entre 1950 e 1970 (Salm, 2007:17), muitas pesquisas nos últimos 15 anos demonstram que a desigualdade não é funcional para o desenvolvimento, tampouco um traço inerente à modernização. "Ao invés de favorecer o crescimento, a desigualdade inicial lhe impõe obstáculos" (Kliksberg, 2002:19), sendo sua persistência por muitas vias prejudicial ao crescimento (Rodríguez, 2005:230). Além disso, o crescimento, quando ocorre, nem sempre cria condições de maior eqüidade. Na América Latina, nas décadas de 1980 e 1990, o crescimento não provocou o esperado efeito de gotejamento (trickle down effect), senão em patamares muito modestos (Barros et alii, 2007), e não chegou aos setores mais desfavorecidos, para tirá-los da pobreza. Reformas macroeconômicas, centradas na liberação dos mercados, não evitaram nessas duas décadas importantes incrementos da desigualdade (Kliksberg, 2002). Mesmo se desacompanhado de tendências de concentração de renda, o crescimento provocaria por si mesmo um efeito muito lento sobre a diminuição das desigualdades no Brasil ${ }^{5}$. O crescimento econômico não é empecilho à redução das desigualdades, mas, sem alte- 
rar-se por outros meios o padrão de alta desigualdade, ele não é capaz de produzir mudanças profundas na distribuição da renda e na pobreza.

Em segundo lugar, a política econômica precisa estar direcionada aos setores mais pobres para que induza o crescimento dos mesmos e gere efeitos redistributivos diretos. Necessita estar associada a medidas redistributivas e à "difusão de inovações que elevem a produtividade das atividades voltadas ao suprimento de carências que distinguem a vida dos mais pobres" (Salm, 2007:293), de modo que lhes toque "uma trajetória de elevação mais acelerada dos seus rendimentos" (Dedecca, 2007:300). A pobreza é menos sensível aos efeitos do crescimento econômico quando o nível de desigualdade é maior (Barros et alii, 2007:333). Nos casos de disparidades no acesso a recursos produtivos, como a terra, estudos concluem que "as estratégias convencionais de luta contra a pobreza centradas no crescimento, em programas sociais dirigidos aos pobres e em redes de assistência têm resultados limitados, já que não afetam as bases da desigualdade que vai condicionar o crescimento e seus efeitos sobre os pobres" (Kliksberg, 2002:29). Do ponto de vista das oportunidades de emprego e renda, a simples expansão de sua oferta através dos parâmetros atuais de empregabilidade, seletivos em termos de conhecimento e de experiência prévia, redunda em níveis consideravelmente menores de inserção dos pobres no mercado de trabalho, ampliando a segmentação deste e penalizando-os novamente com a escassez de oportunidades de emprego.

Em terceiro lugar, medidas redistributivas direcionadas ao aumento da eqüidade produzem efeitos positivos sobre o crescimento econômico, introduzindo circuitos virtuosos de desconcentração e crescimento (Medeiros, 2005). Melhoras na renda dos pobres geram aumentos sensíveis em seus gastos com a preservação e formação do seu capital humano, mediante despesas em nutrição, saúde e educação do núcleo familiar, as quais representam as bases mínimas para a elevação durável de sua inserção econômica e seu nível de vida. Entre os pobres, a "propensão marginal a consumir bens desta ordem é muito alta, visto que são decisivos para a existência e percebidos como tais" (Kliksberg, 2002:21). A diminuição da instabilidade de rendimentos e da insegurança econômica das famílias pobres produz o mesmo efeito. Por outro prisma, a eqüidade favorece o aparecimento e o fortalecimento do capital social, fator importante do desenvolvimento econômico e social, que "valorizará a cultura popular, democratizará o acesso à cultura, 
contribuirá para a elevação da auto-estima dos setores desfavorecidos, incrementará a sua participação, promoverá e estimulará mecanismos de cooperação, criará vínculos de solidariedade atuantes no interior da sociedade" (idem:95).

O equacionamento da desigualdade requer atacar o problema da transferência de renda e de distribuição da riqueza. Alterar o padrão de concentração impõe um crescimento orientado a certos setores, em paralelo a medidas redistributivas. Tais medidas, quando orientadas à ativação econômica dos setores menos favorecidos, e não apenas a melhorias em sua capacidade de consumo, são as mais indicadas para provocar efeitos benéficos sobre a eqüidade e o desenvolvimento social e econômico.

\section{O VALOR DA ATIVAÇÃO ECONÔMICA DOS POBRES}

Ações efetivas para romper a lógica reiterativa das desigualdades implicam reconhecer e promover o protagonismo dos pobres como requisito para que políticas em seu favor sejam sustentáveis e duráveis. Em primeiro lugar, para que sejam sujeitos econômicos, minimamente capazes de reter para si a riqueza que produzem e incrementá-la paulatinamente, a partir dos ativos materiais, intelectuais e relacionais que possuem e da exploração da sua capacidade de trabalho. Em segundo lugar, para que esse empreendedorismo reverta igualmente em capital social e em recursos de poder, necessários à defesa de seus interesses, contrários àqueles a quem interessa, na outra ponta, preservar sua posição através da perpetuação das desigualdades.

Experiências em diferentes países atestam a eficiência dos estímulos às pequenas unidades produtivas, cujas respostas, densas em investimentos, propiciam a médio prazo a formação de uma base produtiva dinâmica, geradora de postos de trabalho. Os agentes econômicos mais desguarnecidos, se apoiados, investem nas bases mínimas (nutrição, saúde, educação) necessárias à qualificação dos seus recursos humanos. Investir nessa direção proporciona que os mesmos lancem mão de suas capacidades potenciais, recuperem e formem ativos básicos (terras, bens de capital, qualificações educativas) que lhes permitam organizar a vida familiar, incrementar e estabilizar seus rendimentos. Ademais, pessoas sistematicamente expostas à carência, ao desemprego e à vulnerabilidade ficam minadas em sua auto-estima e se auto-excluem da condição de agentes (Dejours, 2007). Necessitam de 
oportunidades de reconstrução pessoal, de experiências positivas de participação e reconhecimento, não apenas da recuperação de sua renda de consumo. Nos dias atuais, é igualmente importante fortalecer iniciativas e organizações autóctones que possam defender e restabelecer o tecido social popular, severamente cerceado e agredido pela insegurança e violência constante que o atinge diretamente, formando com isso uma comunidade cívica assente em mecanismos de participação e em práticas de solidariedade (Putnam, 1996).

A erradicação da pobreza não será possível pela via unilateral de ações governamentais, como os programas de transferência de renda. O êxito de tais programas depende de chances e espaços nos quais os afetados pelas desigualdades possam escolher o caminho para atuar como agentes na recuperação de sua dignidade (Asseburg, 2007). Deve-se, então, ter em conta os padrões de privação de capacidades (Sen, 1999; 2001) que afetam as pessoas. Sem sua superação, elas não reagirão adequadamente diante de oportunidades mais favoráveis, para tirar-lhes proveito visando à melhoria de suas condições de vida.

\footnotetext{
“Não basta a assistência econômica por parte do Estado; deve-se promover o desenvolvimento de capacidades que permitam às pessoas gerar rendas por sua própria conta e, desta forma, sair por si mesmas da pobreza. Deve-se fortalecer os mecanismos para a transformação de capacidades em rendimentos, que por sua vez possibilitam o desenvolvimento de funcionamentos valiosos e novas capacidades" (Rodríguez, 2005:223).
}

Por outro ângulo, o combate à nova exclusão social, através de uma rede de proteção social que integre programas distributivos, de reinserção social e de previdência social, deve conter políticas "portadoras de novos significados para esse novos sujeitos sociais", considerando "a pluralidade de suas estratégias de sobrevivência, da afirmação de suas diferenças e identidades" (Cohn, 2003:74).

As experiências de economia solidária sinalizam traços desse protagonismo, desde seus primórdios, no correr dos anos 1980, quando sua presença polimorfa e difusa no tecido social as deixavam aparentemente alheias aos principais embates travados no campo popular. Movendo-se no terreno concreto das lutas pela sobrevivência, reunindo pessoas por meio de práticas participativas, de cooperação e autogestão, essas experiências inovaram ao buscarem soluções coletivas de iniciativa própria para demandas cujo atendimento se buscava anteri- 
ormente por meio de pressões de massa que acionassem a capacidade provedora do Estado (Scherer-Warren, 1996; Gaiger, 2004b). Sua expansão e seu fortalecimento posterior referendaram a hipótese de que cumpririam um papel apreciável na formação de indivíduos e grupos com capacidade de ação, advinda da vivência de reorganização da vida cotidiana e, por extensão, das múltiplas esferas da vida social (Gadotti, 1993).

Considerando as limitações do crescimento econômico como instrumento eficaz de redução da pobreza e das desigualdades, ao lado da insuficiência das políticas compensatórias, os empreendimentos solidários de geração de trabalho e renda merecem atenção ${ }^{6}$. Em primeira mão, eles adotam o princípio de fortalecer a capacidade de ação dos empobrecidos. De modo efetivo, mesmo se variável e reversível, afastam-se da lógica dominante de produção de bens e de reprodução social ao eliminarem a divisão entre trabalhadores e meios de produção, entre produção e apropriação dos frutos do trabalho. Suas fragilidades inegáveis (Gaiger, 2004a) encontram uma via de compensação em fatores cujo efeito positivo deriva do caráter associativo e cooperativo por eles incorporado (Gaiger, 2006). Em seu âmbito interno e em seu perímetro social, como buscaremos evidenciar, não reprisam as condutas alimentadoras da dualização social e da injustiça.

Não se imagina com isso que a economia solidária possa alterar com suas forças a equação estrutural da pobreza e das desigualdades. De resto, porque a desigualdade econômica existente entre os $50 \%$ mais pobres, em que claramente se situam as iniciativas em questão, corresponde apenas a $10 \%$ da desigualdade total de renda no país (Medeiros, 2005:51), não podendo, assim, a economia solidária interferir senão no aumento ou na estabilidade dos rendimentos internos aos extratos situados nessa faixa. Além disso, a maioria dos empreendimentos em seu estágio atual encontra-se às voltas com sua sobrevivência a curto e médio prazos. Sendo realista, convém antes indagar quais efeitos positivos a ativação solidária dos trabalhadores causa sobre eles próprios. A valorização do protagonismo dos atores econômicos como um elemento estratégico para o seu êxito é correntemente aplicada àqueles segmentos patronais que empregam os trabalhadores. Quando estes resolvem prescindir de patrões e empregar por sua conta seus recursos produtivos, direcionando para esse fim o seu fundo de trabalho comum (Coraggio, 1999:142-145), o que sucede? Quando algumas das ré- 
deas da sua vida econômica passam às suas mãos, os trabalhadores reproduzem ou reduzem as desigualdades?

Essa é a questão explorada empiricamente neste artigo. Atacar esse problema no interior das unidades produtivas, introduzindo princípios igualitaristas, no plano econômico, político e cultural, constitui uma providência indispensável à redução das desigualdades. Se os trabalhadores o fazem, quando se oferece a oportunidade, não é irrelevante. Pela índole dos empreendimentos solidários, é de esperar que tomem medidas nesse sentido. Sua natureza associativa, distinta das organizações estruturadas em relações contratuais e hierárquicas, deve exercer uma força instituinte de condutas e valores, com reflexos nas condições de trabalho, na renda e na qualidade de vida dos seus membros. Contudo, é insuficiente presumi-lo ou apenas constatá-lo genericamente, sem examinar as práticas que traduzem amiúde essa inclinação igualitarista, de modo a identificar as ações mais significativas e aquilatar seus efeitos e limites. Do mesmo modo, é importante compreender as condições sociais que favorecem as práticas igualitárias, em particular quando decorrem de deliberações dos próprios empreendimentos, à proporção que sua lógica de funcionamento vai tornando racionalmente preferível, ou mais lógico, adotar princípios igualitaristas.

\section{UMA PESQUISA EMPÍRICA COMPARADA}

As condições de gênese desses formatos produtivos, sua morfologia e seus padrões de desenvolvimento são objeto de nossas pesquisas empíricas desde 1993. Em dado momento, a percepção de que essas iniciativas alcançam consolidar-se e atingir níveis de acumulação que as habilitam a um processo de crescimento sustentado, não obstante o estado geral de fragilidade que as caracterizam, conduziu as pesquisas à identificação dos fatores explicativos desse desempenho positivo, focalizando propositalmente empreendimentos solidários com razoável êxito na tarefa de conciliar suas premissas ideológicas e organizacionais com sua viabilidade econômica.

Uma pesquisa a respeito, em 1998, teve por objeto 30 experiências associativas de geração de trabalho e renda, situadas em quatro regiões do Estado do Rio Grande do Sul, exemplares da sua diversidade geoeconômica, social e política. Os critérios de seleção utilizados cobraram evidências iniciais dos empreendimentos quanto a: a) autonomia eco- 
nômica e financeira; b) organização e funcionamento democrático, independente de externalidades; c) envolvimento comunitário e social; d) relevância econômica para os seus membros, não se constituindo apenas em atividade destinada a gerar renda complementar; e) ao menos três anos (em 1997) de funcionamento. Além do estudo sobre a formação da economia solidária nas regiões em tela e de dados prévios sobre casos antes investigados, procedeu-se à coleta de informações em visitas aos empreendimentos, análise de documentos, contatos e reuniões com lideranças populares e organizações de apoio. Uma vez consignados em planilhas específicas, os dados foram exaustivamente discutidos, obtendo-se uma descrição fiel de cada empreendimento e uma visão analisada de sua dinâmica interna, com base em parâmetros homogêneos que facultassem explorar as possibilidades da análise comparativa entre os empreendimentos.

Os estudos comparativos ultrapassam a unidade mínima de análise e servem para elucidar regularidades e linhas de variação em um conjunto de organizações, dotadas por hipótese de um padrão de funcionamento e formando, assim, uma totalidade. Da análise dos casos singulares, passa-se ao exame relacional de suas propriedades (Bruyne, Herman e Schoutheete, 1974), das quais se extraíram, na pesquisa em questão, os aspectos sistêmicos dos empreendimentos que os dispõem ao êxito e à longevidade (Gaiger et alii, 1999). A essa abordagem sincrônica, foi acrescentada uma perspectiva diacrônica em 2003, com a realização de uma segunda pesquisa sobre os mesmos empreendimentos ${ }^{7}$, similar quanto ao foco e à metodologia. Ao cotejar dois momentos do percurso dessas experiências, com base na análise de suas variações organizacionais e no impacto das mesmas sobre seus níveis de desempenho, tencionava-se estabelecer as suas linhas de evolução de forma mais segura e conclusiva.

Aos procedimentos de coleta e tratamento de dados antes empregados, a pesquisa de 2003 acrescentou uma grade de 60 indicadores, objetivando maior precisão na avaliação de cada experiência e melhor comparabilidade com os demais empreendimentos e com os dados de 1998. Esses indicadores dizem respeito a características e práticas de autogestão, cooperação, eficiência e viabilidade, dimensões do conceito de empreendimento econômico solidário (Gaiger, 2003), cuja idéia central reside na simbiose que se estabelece entre aspectos solidários e empreendedores dessas iniciativas, engendrando um círculo virtuoso que se vale das forças da associação e do trabalho cooperativo ${ }^{8}$. Formulados 
mediante a decomposição metodológica desse conceito, os indicadores compõem um dispositivo analítico útil, ao integrarem a coleta, a consignação e a interpretação dos dados, sob distintos ângulos e critérios. Sua aplicação a cada empreendimento, com base nos dados empíricos previamente validados, traduziu-se em uma pontuação conforme a seguinte regra: prática inexistente: -1 ; observada parcialmente: +1 ; observada plenamente: $+2^{9}$; sem informação ou aplicabilidade: 0 . Para cada dimensão, indicador e empreendimento contou-se com pontuações individuais e opções de ordenamento e classificação das características observadas.

Como mencionado, o corpus dessas pesquisas representa o lado supostamente mais alternativo e bem-sucedido da economia solidária, não seu perfil médio. Com essa ressalva, os empreendimentos foram escolhidos de modo a expressarem a diversidade econômica, institucional e regional da economia solidária no Rio Grande do Sul, abarcando diferentes categorias sociais e tipos de atividade econômica.

Tabela 1

Categorização Econômica dos Empreendimentos

\begin{tabular}{l|c}
\hline Atividades & N $^{\mathbf{0}}$ de EES \\
\hline Produção agrícola & $6(19 \%)$ \\
Alimentação & $5(16 \%)$ \\
Comercialização & $5(16 \%)$ \\
Vestuário & $5(16 \%)$ \\
Misto & $3(9 \%)$ \\
Triagem de resíduos sólidos & $3(9 \%)$ \\
Serviços gerais (ou de trabalho) & $3(9 \%)$ \\
Metalurgia & $2(6 \%)$ \\
\hline Total & $\mathbf{3 2 ( 1 0 0 \% )}$ \\
\hline
\end{tabular}

Fonte: Pesquisa Autogestão, Eficiência e Viabilidade dos Empreendimentos Econômicos Solidários (www.ecosol.org.br).

A caracterização dos EES segundo as propriedades já citadas e outras, como a população envolvida, o contexto inicial e o regime jurídico, permitiu subdividi-los em segmentos: grupos de empreendimentos com características socioeconômicas e culturais similares, em tese explicativas da sua dinâmica e de suas possibilidades de desenvolvimento (Tabela 2). Em cada segmento, procuraram-se observar traços particulares, do ponto de vista solidário e empreendedor. O exame das con- 
comitâncias e repulsões entre os diferentes indicadores, mediante um raciocínio por homologia, exercido não diretamente sobre os objetos empíricos, mas sobre as propriedades de tais objetos e as relações entre as mesmas (Bruyne, Herman e Schoutheete, 1974:216), completou, no essencial, o percurso analítico executado.

Tabela 2

Divisão dos Empreendimentos por Segmentos

\begin{tabular}{l|c}
\hline Segmentos & № de EES \\
\hline Pequena associação ou grupo familiar & $9(28 \%)$ \\
Associação de pequenos produtores rurais & $7(22 \%)$ \\
Coletivo de assentamento rural & $6(19 \%)$ \\
Cooperativa de produção & $4(12,5 \%)$ \\
Associação de triagem de resíduos & $3(9 \%)$ \\
Cooperativa de trabalho & $3(9 \%)$ \\
\hline Total & $\mathbf{3 2 ( 1 0 0 \% )}$ \\
\hline
\end{tabular}

Fonte: Pesquisa Autogestão, Eficiência e Viabilidade dos Empreendimentos Econômicos Solidários (www.ecosol.org.br).

Ao verificar a presença de fatores explicativos do êxito dos empreendimentos solidários, com base na hipótese de que estariam dotados de uma racionalidade singular, a pesquisa de 2003 levantou simultaneamente indícios da existência de princípios igualitaristas e de seus efeitos práticos, explícitos ou implícitos em vários dos indicadores utilizados. Aspectos dessa ordem serão discutidos a seguir, do ponto de vista da eqüidade econômica, política e cultural.

\section{EFEITOS SOBRE A EQÜIDADE ECONÔMICA}

O diferencial dos EES averiguado, no tocante à redução das desigualdades econômicas, especialmente entre os detentores da força de trabalho e os detentores do capital, decorre do grau com que superam esse antagonismo, ao converterem os trabalhadores em proprietários associados do empreendimento e fazerem fluir para eles próprios os frutos da atividade econômica, em proporções correspondentes aos seus aportes em trabalho. Desse modo, os excedentes produzidos deixam de ser drenados pelo detentor exclusivo do capital e revertem para os trabalhadores, sob a forma de retribuições diretas ou como capital por eles compartilhado, representando um incremento do patrimônio pessoal e coletivo. 
Esses processos não se põem em marcha uniformemente: dependem da natureza dos EES e da abrangência e profundidade com que socializam os meios de produção e o trabalho. A simples comparação entre os segmentos antes mencionados permite estimar a existência de empreendimentos com elevado grau de socialização, como as cooperativas de produção, os coletivos em assentamentos rurais e as associações de reciclagem, em que a força de trabalho de cada sócio, em geral, é requerida integralmente. Em outros casos, como as cooperativas de trabalho, o EES pode representar uma opção complementar de renda, conciliável com as ocupações individuais: a cooperação no trabalho passa a ter sentido apenas em alguns momentos da atividade laboral ou de gestão do empreendimento. Como ocorre nas associações de pequenos produtores rurais, criadas às vezes para fins de comercialização e defesa dos interesses de agricultores familiares, nem sempre as bases materiais e os propósitos do empreendimento induzem à socialização plena dos meios de produção.

Não obstante essa diversidade, faz sentido avaliar até que ponto os EES em seu conjunto manifestam tendências ou apresentam resultados tangíveis na direção apontada, de menor divisão entre capital e trabalho e de maior eqüidade. Para este fim, vale examinar indicadores incidentes sobre dois aspectos correlacionados: a) a constituição dos trabalhadores dos EES ao mesmo tempo como seus proprietários; b) o usufruto por eles, a partir dessa condição similar, dos resultados e benefícios gerados pelo empreendimento. As tabelas a seguir referem-se a cada um desses aspectos ${ }^{11}$.

Tabela 3

Socialização da Base Material e Produtiva

\begin{tabular}{l|l|c|c}
\hline & \multicolumn{1}{|c|}{ Indicadores Selecionados } & $\mathbf{( \% )}$ & Classificação \\
\hline C1 & Propriedade coletiva dos principais meios de produção & 75 & $23^{\circ}$ \\
A12 & Aporte em capital e trabalho similar entre sócios & 78 & $30^{\circ}$ \\
A10 & Trabalhadores não associados apenas em caráter restrito & 91 & $5^{\circ}$ \\
A11 & Atividades-fim realizadas apenas pelos sócios & 82 & $15^{\circ}$ \\
C2 & Processo de trabalho coletivo & 94 & $5^{\circ}$ \\
\hline
\end{tabular}

Fonte: Pesquisa Autogestão, Eficiência e Viabilidade dos Empreendimentos Econômicos Solidários (www.ecosol.org.br).

A presença de meios de produção de propriedade comum, importantes e empregados na atividade produtiva do EES [C1], certamente é um 
indicador indispensável do grau de socialização da sua base material. Apenas em dois EES verificou-se a preservação por inteiro da propriedade individual dos instrumentos de trabalho e demais fatores produtivos. Em 75\% dos casos, observou-se correspondência com o indicador, em $47 \%$ dos empreendimentos, de modo decisivo para o seu funcionamento, um fato relevante, visto que muitos deles operam sob bases materiais de natureza individual e familiar, evidenciando que a dinâmica solidária induz, ao menos parcialmente, à sua socialização ou então agrega, àquela base anterior, novos meios de produção de propriedade e uso coletivo. Por outro lado, o comportamento desse indicador, em particular diante daquele que veremos a seguir e das situações de maior envolvimento dos trabalhadores na gestão do empreendimento, denota que a propriedade coletiva não é um pressuposto básico ou uma garantia de que haja implicação similar dos indivíduos. A chave parece residir no grau de cooperação, na gestão e no trabalho, ainda que o mesmo esteja apoiado em bens de produção e em economias parcialmente individualizadas (Gaiger, 2004a:397).

A homogeneidade das contribuições em capital ou trabalho entre os sócios [A12] indica justamente se existem sócios mais proprietários ou mais trabalhadores que os demais, em vista dos prováveis desequilíbrios que tal fato viria a acarretar no grau de influência de uns sobre outros ou na divisão dos resultados. Vice-versa, quando todos os sócios atribuem alto grau de importância ao empreendimento, a dedicação ao mesmo e o enfrentamento de riscos tendem a ser uniformes, $\mathrm{o}$ que evita discrepâncias entre os aportes individuais e dispensa a existência de diferentes qualidades de sócios ou participantes (Gaiger et alii, 1999). Em quase $80 \%$ dos EES estudados, as diferenças observadas são secundárias, desprezíveis em $44 \%$ deles. Restam $20 \%$ dos EES que não cumprem o quesito, fato que se explica pelo rumo tomado desde as suas condições de partida: nos casos em que estas eram objetivamente desiguais, predominou a tendência ao aprofundamento das diferenças e concentraram o patrimônio e o poder de decisão nas mãos de poucos sócios-fundadores, dando lugar a empresas convencionais, não obstante suas práticas de solidariedade e de atenção aos trabalhadores. Entre os EES mais bem-sucedidos, pelo contrário, é típica a presença de interesses e graus de participação semelhantes ${ }^{12}$.

A paridade entre os sócios teria um valor muito relativo se houvesse ao mesmo tempo a contratação habitual de outros trabalhadores [A10], pois se estariam introduzindo relações assalariadas ou alguma de suas 
variantes, com o seu corolário de separação entre o capital e o trabalho. Essa prática foi observada freqüentemente em apenas 9\% dos casos, inexistindo ou sendo muito excepcional em 75\% deles. Por conseguinte, as prerrogativas dos sócios, no plano dos direitos e da distribuição dos benefícios, via de regra alcançam todos os trabalhadores. Nota-se ainda que, se há $25 \%$ de EES que contam de algum modo com trabalhadores não-associados, apenas em $18 \%$ dos EES pesquisados essas contratações não visam preencher funções específicas ou complementares [A11], tais como assessoria técnica e contabilidade, diferentes da atividade-fim do empreendimento e das características ocupacionais dos seus membros.

Pode-se, então, concluir que os EES têm sua base produtiva formada por trabalhadores associados cujo labor sustenta o empreendimento e para os quais fluem os seus resultados diretos e indiretos. Se é bem verdade que do contrário não seriam classificáveis como empreendimentos econômicos solidários, confirmá-lo a partir de uma análise minuciosa é de interesse. Por isso, vale ainda acrescentar que a adoção de processos coletivos de trabalho [C2] verifica-se com nitidez em 69\% dos EES, parcialmente em $25 \%$. Essa fração minoritária deve-se em boa medida à natureza da atividade econômica, a exemplo da prestação de serviços por cooperativas de trabalho, e ao foco de atuação do EES, por vezes situado na comercialização da produção familiar ou na conveniência de compatibilizar o trabalho no EES com outras atividades, como se observou em uma confecção de peças de vestuário onde as costureiras são agricultoras. Os EES com melhor desempenho global e com melhores resultados atendem plenamente a esse quesito.

Tabela 4

Divisão Eqüitativa dos Benefícios Econômicos e Sociais

\begin{tabular}{l|l|c|c}
\hline & \multicolumn{1}{|c|}{ Indicadores Selecionados } & $\mathbf{( \% )}$ & Classificação \\
\hline C4 & Remuneração pelo trabalho & 94 & $5^{-}$ \\
C5 & Minimização das diferenças de remuneração & 84 & $13^{\circ}$ \\
E1 & Remuneração igual ou superior ao mercado & 62,5 & $45^{\circ}$ \\
C11 & Assistência a membros desfavorecidos & 54 & $47^{\circ}$ \\
C6 & Práticas de reciprocidade e ajuda mútua & 87 & $12^{\circ}$ \\
E3 & Fundos sociais (seguridade, saúde, descanso etc.) & 31 & $58^{\circ}$ \\
E10 & Preservação do quadro de associados & 62,5 & $54^{\circ}$ \\
\hline
\end{tabular}

Fonte: Pesquisa Autogestão, Eficiência e Viabilidade dos Empreendimentos Econômicos Solidários (www.ecosol.org.br). 
Ao avaliarem-se os resultados econômicos dos EES e sua divisão entre os sócios (Tabela 4), percebem-se ganhos reais, em particular quanto à eliminação das disparidades na distribuição do trabalho e da renda ${ }^{13}$, um fato a destacar, uma vez que não deriva de um mero voluntarismo igualitarista, mas da superação da essência desigual da relação assalariada, com o seu princípio intrínseco de subordinação e alienação.

A remuneração dos sócios dos EES depende, via de regra, unicamente dos seus aportes em trabalho [C4], com duas exceções, nas quais, em realidade, alguns membros são sócios-proprietários, auferindo dividendos exclusivos. No mais, a inexistência de apropriação do trabalho alheio suspende o ciclo de acumulação privada do capital, convertido em capital social indivisível, destinado ao consumo ou a investimentos por deliberação coletiva. Nessas condições, é de se esperar uma política interna de contenção das diferenças de remuneração, fato registrado em $84 \%$ dos EES [C5], em grau bastante apreciável em 59\% dos casos. Não é certo, contudo, que essa remuneração monetária supere em média aquela do mercado de trabalho: pelos dados disponíveis, isso ocorreria em $25 \%$ dos EES, através, por exemplo, de reajustes acima do piso negociado no dissídio da categoria correspondente, ou da cotação da produção primária dos sócios em valores acima da concorrência. Em $37,5 \%$ dos EES, a remuneração equivaleria à oferecida pelo mercado; casos de remuneração inferior corresponderiam a 9\%. Como os EES agregam às vezes diferentes atividades e ocupações, algumas representando um ganho adicional à renda principal auferida na produção familiar ou em negócios privados, e, além disso, renunciam à retirada individual das sobras para fins de capitalização, fato notório no caso das cooperativas de produção, os resultados dessas comparações diretas são relativos ${ }^{14}$.

No capítulo de ganhos parciais, destacam-se as práticas de assistência a membros de EES em situações de dificuldade (doenças, problemas familiares etc.), costumeiras ou previstas formalmente em $41 \%$ dos EES, eventuais em 13\% [C11]. Práticas espontâneas de ajuda mútua entre os trabalhadores [C6], além daquelas instituídas formalmente, parecem acontecer com freqüência em 53\% dos casos, inexistindo em menos de $10 \%$ dos EES estudados. Olhando-se a questão mais amplamente, com base em outras fontes de campo, é lícito afirmar que o modo como se vivencia o trabalho proporciona em muito casos uma série de satisfações adicionais, além da renda e dos benefícios econômicos indiretos, sobretudo a posse coletiva do capital do empreendimento. Em 
diversos depoimentos, a experiência de ser sócio-trabalhador, em pé de igualdade com os demais, ao mesmo tempo que sócio-proprietário, gestor do negócio com direito a voz e voto, é altamente valorizada. $\mathrm{O}$ mesmo aplica-se à experiência do trabalho como algo edificante e oportunidade de cultivo pessoal. O lado gratificante do trabalho conjuga-se à sua percepção como um valor elevado, neutralizando até certo ponto a sua face penosa e as incertezas quanto ao futuro.

Limites e dificuldades consideráveis são observadas no campo da seguridade social e da ampliação do quadro de sócios. Os níveis modestos de acumulação, de empreendimentos desprovidos de capital e de tecnologia desde seu nascedouro, parecem ser responsáveis pela incapacidade observada de expandir as atividades, multiplicar dividendos e oferecer garantias sociais aos trabalhadores [E3]. De modo geral, os membros dos EES não dispõem dos direitos trabalhistas assegurados pelo trabalho formal, tais como descanso remunerado, repouso por razões de saúde, seguros e previdência. Valem-se às vezes da sua condição profissional anterior ou externa ao EES (caso de aposentados, autônomos com recolhimento ao Instituto Nacional do Seguro Social INSS etc.). Tampouco as cooperativas evidenciam essas garantias, praticamente inexistentes nas associações de produção e nas microempresas familiares. Embora haja planejamento e projetos, os EES conseguem a duras penas uma acumulação minimamente progressiva de capital, o que lhes impede de preservar recursos para a garantia dos direitos sociais e investimentos futuros importantes. Nesse aspecto, a economia solidária não se distancia da realidade da economia informal.

O que os EES garantem é trabalho e renda em condições razoavelmente estáveis. Vêem-se instados a economizar em seus ideais sociais para viabilizarem-se a curto e médio prazos. A prioridade é a sua sobrevivência e consolidação, antes de multiplicarem os benefícios ou de estendê-los a terceiros ou a novos associados. Por isso, no espaço de cinco anos, o quadro de sócios preservou-se integralmente apenas em $25 \%$ deles, parcialmente em 37,5\% [E10]. Alguns EES, zelosos em não empregar mão-de-obra externa assalariada, buscando equilibrar a força de trabalho dos associados à demanda, incorrem em uma equação inversa, na qual a demanda termina fixando-se de acordo com a capacidade produtiva já instalada. Uma situação potencialmente estagnante: por não produzirem mais nem obterem um retorno maior, os associados não logram acumulação e, por conseguinte, não cresce o negócio, tampouco a renda pessoal auferida. Não gerando maior capital, os tra- 
balhadores não conseguem pô-lo à disposição de si próprios e da expansão da sua força de trabalho. De outro lado, manter os postos de trabalho é a prioridade, mesmo ao preço de menores retribuições individuais, porque significa preservar a capacidade produtiva do EES, meio de subsistência e propriedade comum dos trabalhadores. Essa finalidade, intrínseca ao EES, determina em verdade a sua racionalidade específica ${ }^{15}$.

\section{EFEITOS SOBRE A EQÜIDADE POLÍTICA}

A desigualdade do poder em nossa sociedade manifesta-se nas instâncias da vida cotidiana e nas diferenças de reconhecimento e efetivação de direitos e participação cidadã. Sem a vivência desses direitos nos espaços de proximidade, caracterizados pelas interações diretas, compromete-se desde a raiz a premissa da igualdade política e o preceito do bem comum. Não há como se consolidarem a noção mais ampla de esfera pública e a aspiração democrática. Cabe então avaliar como os empreendimentos solidários materializam para os trabalhadores uma condição de sujeitos de seus coletivos de trabalho, selando as bases do seu protagonismo.

Tabela 5

Democracia Interna

\begin{tabular}{|c|c|c|c|}
\hline & Indicadores Selecionados & $(\%)$ & Classificação \\
\hline A2 & Princípio um associado, um voto & 87,5 & $1^{\circ}$ \\
\hline A1 & $\begin{array}{l}\text { Decisões fundamentais tomadas pelo conjunto de as- } \\
\text { sociados }\end{array}$ & 88 & $9^{\circ}$ \\
\hline $\mathrm{C} 10$ & $\begin{array}{l}\text { Elevado comparecimento nas instâncias deliberativas } \\
\text { e consultivas }\end{array}$ & 87 & $11^{\circ}$ \\
\hline A9 & Socialização das informações entre os membros & 78 & $19^{\circ}$ \\
\hline A3 & Eleições diretas e livres dos dirigentes & 72 & $21^{\circ}$ \\
\hline A6 & Regularidade das reuniões decisórias & 85 & $25^{\circ}$ \\
\hline A13 & $\begin{array}{l}\text { Envolvimento dos membros na gestão cotidiana do } \\
\text { trabalho e do empreendimento }\end{array}$ & 72 & $43^{\circ}$ \\
\hline A14 & Participação igualitária de sócios homens e mulheres & 59 & $45^{\circ}$ \\
\hline A7 & Renovação dos quadros diretivos & 69 & $48^{\circ}$ \\
\hline A4 & Voto secreto nas decisões fundamentais & 25 & $56^{\circ}$ \\
\hline
\end{tabular}

Fonte: Pesquisa Autogestão, Eficiência e Viabilidade dos Empreendimentos Econômicos Solidários (www.ecosol.org.br). 
O primeiro bloco de indicadores da Tabela 5 [A2 a A3] enuncia a observância de um conjunto de regras e práticas essenciais à gestão participativa e democrática. Não obstante as variações existentes entre os indicadores, predominam situações em que os sócios possuem iguais possibilidades de influência (pela prerrogativa de participação e manifestação) e de decisão (pelo acesso às informações e pelo voto). O princípio um associado, um voto [A2] é inteiramente respeitado em $88 \%$ dos EES, não o sendo naqueles poucos, já indicados, em que existem outros trabalhadores além dos sócios. Nesses mesmos casos e em alguns outros (perfazendo 12\%), as decisões fundamentais em regra não são tomadas pelo conjunto dos membros [A1], tampouco se observa um comparecimento expressivo nas instâncias deliberativas e consultivas [C10]. A eleição dos dirigentes normalmente é livre e direta [A3], salvo nas exceções já nomeadas, em alguns EES cuja natureza semifamiliar conduz a uma escolha por indicação, sem uso formal do voto, e naqueles EES de estrutura mais complexa, em que o voto é prerrogativa dos representantes das unidades menores filiadas. No cômputo geral, a estrutura de poder dos EES distancia-se daquela das empresas e organizações privadas, em que proprietários, gestores e trabalhadores exercem funções inconfundíveis, com suas respectivas posições na hierarquia de comando.

Isso não significa que o poder esteja plenamente distribuído e seja igualmente exercido pelos membros dos EES. A socialização do poder é aceita como princípio reitor, imanente à razão de ser e à identidade das cooperativas e associações. Desde 1998, quando se realizou a primeira pesquisa, alguns EES evoluíram, no sentido de superar lideranças paternalistas ou intervencionistas. Ainda assim, a efetivação dos princípios democráticos, através de práticas participativas e autogestionárias, sofre limitações. Os motivos residem nas dificuldades de instituir mecanismos plenamente condizentes com tais princípios, devido ao ritmo cotidiano absorvente e às vezes imprevisível dos empreendimentos, às suas dimensões e estruturas mais complexas ou às diferenças de interesse e de envolvimento dos sócios.

Assim, nos EES de maiores dimensões, os dirigentes máximos não são eleitos diretamente pelos membros que compõem a base [A3]. No caso dos EES rurais, os desafios que o elevado número de associados impõe à autogestão ainda são multiplicados pela sua dispersão geográfica. A mobilização do corpo de associados aparece como um dos grandes obstáculos. Muitas vezes, a saída do impasse requer a centralização de 
tarefas diárias e tomadas de decisões funcionais num pequeno círculo de dirigentes, que convocam o restante do quadro de associados para prestação de contas anuais ou para assembléias extraordinárias. No extremo oposto dos pequenos grupos, os fatores limitantes das práticas solidárias são os diversos níveis de dedicação dos associados ao empreendimento, que variam de acordo com as possibilidades e interesses de cada um, fruto por vezes de condições preestabelecidas de participação, especialmente no que tange às desigualdades na posse dos meios necessários ao desenvolvimento da atividade produtiva.

A regularidade das reuniões decisórias [A6], presumivelmente favorável à participação dos sócios, experimenta grande variação, não sendo observável em 15\% dos EES, contra $41 \%$ em que é prática constante. Essa mesma cifra corresponde ao total de EES em que o envolvimento dos sócios com a gestão se verifica regularmente [A13]. O gradiente denota algum nível de especialização dos gestores e de separação entre os mesmos e os demais sócios-trabalhadores. Em certos casos, o motivo parece ser eminentemente prático, posto que há alternância periódica entre uns e outros e os espaços de deliberação democrática estão garantidos. Em outros, mantêm-se ou reintroduzem-se as bases da divisão social do trabalho, apartando-se, em certa medida, a gestão da produção. Intervêm ainda fragilidades estruturais em alguns EES, como as cooperativas de trabalho, em que as atividades são mais individualizadas e os vínculos de mais caráter contratual, com envolvimentos recíprocos momentâneos, o que na prática converte a gestão na arte de fazer arranjos constantes entre interesses particulares.

Em empreendimentos fundados na livre associação e em objetivos comuns, é plausível imaginar que as práticas democráticas mais freqüentes correspondam a normas fixadas estatutariamente e aceitas com naturalidade. Já outras disposições, como a participação igualitária de homens e mulheres [A14], mesmo formalizadas podem ser menos freqüentes, por contrariarem valores arraigados, perceptíveis em particular no segmento de EES rurais, e outros elementos subjetivos, como a confiança irrestrita do grupo em seu líder, dada a bagagem de experiências que ostenta em aval de suas decisões.

A confiança, associada à franqueza e à transparência, parece explicar por que em $47 \%$ dos EES o voto não é secreto [A4]. Decide-se por consenso ou pelo voto aberto: já que todos devem expressar-se perante o grupo, não há por que deliberar em sigilo, dizem os empreendedores. 
Entretanto, expor-se no momento de decidir envolvendo pessoas impõe assumir as divergências publicamente, com riscos sobretudo diante de lideranças fortes e carismáticas. A hipótese de que a ausência do voto secreto seja sintoma de alguma espécie de coação velada, promovida pelos dirigentes ou por associados mais atuantes, encontra respaldo parcial na constatação de que essa ausência se verifica com certa freqüência em EES nos quais os quadros diretivos tendem menos a renovar-se [A7]. No entanto, ela não é típica dos EES com menor envolvimento dos sócios na gestão cotidiana, tampouco caracteriza os EES com práticas de autogestão globalmente mais modestas. Assim, salvo nos casos em que a isonomia entre os sócios encontra-se rompida pela separação entre proprietários e trabalhadores, ou nos EES em que se constata uma base mais passiva ou desorganizada, dependente de lideranças pessoais, não se poderia concluir pela existência de uma elite dirigente, no sentido de um grupo que se separa da massa de associados e institui mecanismos de auto-reprodução.

Do comparativo entre as duas pesquisas, de 1998 e 2003, sobressai no cômputo geral que a maioria das experiências ruma para a construção de uma postura democrática e autogestionária: enquanto algumas práticas reforçam-se e consolidam-se, outras parecem perder um pouco do seu sentido ou importância, sem prejuízo para a participação e a reciprocidade interna aos grupos.

Tabela 6

Participação Social e Comunitária

\begin{tabular}{l|l|c|c}
\hline & \multicolumn{1}{|c|}{ Indicadores Selecionados } & $\mathbf{( \% )}$ & Classificação \\
\hline C12 & Ações em prol da comunidade & 72 & $42^{\circ}$ \\
C15 & Participação em movimentos sociais & 72 & $34^{\circ}$ \\
C14 & Filiação a instituições representativas & 78 & $13^{\circ}$ \\
V16 & Elevado número de parcerias e articulações & 84 & $16^{\circ}$ \\
C16 & Práticas visando efeito irradiador ou multiplicador & 87,5 & $16^{\circ}$ \\
\hline
\end{tabular}

Fonte: Pesquisa Autogestão, Eficiência e Viabilidade dos Empreendimentos Econômicos Solidários (www.ecosol.org.br).

Com raras exceções, os EES apresentam algum tipo de envolvimento social e algum grau de iniciativa na defesa de interesses coletivos mais amplos. Isto, embora se perceba, pela classificação intermediária dos indicadores da Tabela 6, que suas energias principais são consumidas na organização interna e nas questões de sobrevivência, cobrando um 
alto preço pelo tempo de engajamento em frentes múltiplas de luta, em nome de um novo projeto político, para usarmos o seu linguajar.

As ações espontâneas em prol da comunidade [C12], costumeiras apenas em $41 \%$ dos EES e ausentes em $25 \%$, sinalizam um dado importante para a análise, por serem típicas dos empreendimentos que também exercem a mútua ajuda internamente: a solidariedade entre os membros dos EES assenta-se em uma malha social mais ampla, vindo a reforçá-la pelos laços de reciprocidade que se estabelecem. Assim, a vivência da autogestão e da cooperação no EES torna-o mais suscetível às demandas da comunidade, ao mesmo tempo que promove o seu engajamento nos embates da política local, compromete-o com a fidelidade exemplar aos seus princípios organizativos e carreia ativos políticos e sociais. A hipótese de que se criam circuitos de interação e de troca, fundados em relações não-mercantis e não-monetárias, mas com sentido social e econômico, impulsionando os EES como agentes de uma economia plural (Gaiger e Schüttz, 2005), é avalizada pela conjunção das práticas correspondentes e por sua presença mais expressiva nos EES com melhor desempenho global, solidário e empreendedor. Destacam-se aqui os empreendimentos cuja força reside parcialmente na combinação que fazem entre o exercício da cooperação interna e o envolvimento com a comunidade, com movimentos sociais [C15] e com as suas representações institucionais [C14].

Entre os EES mais bem-sucedidos, quase não se registram experiências isoladas, sem vínculos sólidos com ONGs, movimentos sociais e poder público, sem numerosas parcerias e articulações [V16], no que se opõem diametralmente ao perfil dos empreendimentos menos exitosos. Portanto, estarem conectados ao seu meio [C16] representa para os EES dotar-se de um vetor dinâmico fundamental, não um aspecto adjetivo, complementar. Os EES constituem arranjos produtivos que articulam interesses e atividades sociais, econômicas e políticas. Vários deles passam a ter peso e reconhecimento em seus locais de inserção, onde assumem funções de atores do desenvolvimento ${ }^{16}$.

\section{EFEITOS SOBRE A EQÜIDADE CULTURAL}

Conforme se queira olhar, as disparidades sociais no Brasil começam ou terminam no acesso desigual à educação e em toda sorte de preconceitos, que não poupam os trabalhadores dos empreendimentos solidários. Algumas de suas carências intelectuais são elementares, como 
os modestos níveis de escolarização, que excluem muitos deles do domínio da escrita, do cálculo e do desenvolvimento do raciocínio formal. Ficam igualmente alijados de um conjunto de conhecimentos básicos, vital para que possam gerir seus empreendimentos e transacionar com os mais diversos interlocutores. Ficam ainda em desvantagem quando sua vivência de subalternidade lhes incutiu uma atitude subserviente, oposta à postura altiva e ativa deles esperada, para que, além de produtores diretos, assumam coletivamente o comando de seus negócios. Precisamente porque essas carências e necessidades são postas desta feita diante deles, em um contexto em que vencer tais desafios significa qualificar o trabalho, principal fator produtivo e principal esteio do vínculo associativo com que contam, podem-se imaginar ações visando atenuar aquelas deficiências, através da educação, da aquisição de conhecimentos e de uma práxis reflexiva, que corte o circuito reiterativo da subordinação e promova o desenvolvimento da consciência e de identidades auto-referenciadas.

Tabela 7

Socialização das Informações e dos Bens Culturais

\begin{tabular}{l|l|c|c}
\hline & \multicolumn{1}{|c|}{ Indicadores Selecionados } & $\mathbf{( \% )}$ & Classificação \\
\hline A9 & Socialização das informações entre os membros & 78 & $19^{\circ}$ \\
V13 & Processo de qualificação da força de trabalho & 84 & $30^{\circ}$ \\
V15 & Ações educativas dos associados & 78 & $43^{\circ}$ \\
E4 & Ações de cultura e lazer & 31 & $56^{\circ}$ \\
\hline
\end{tabular}

Fonte: Pesquisa Autogestão, Eficiência e Viabilidade dos Empreendimentos Econômicos Solidários (www.ecosol.org.br).

Uma constatação geral da pesquisa de 1998 indicou a importância de fatores que proporcionam a incorporação e a socialização de saberes profissionais entre os empreendedores, brindando condições propícias ao aprendizado das tarefas de gestão e de condução política do empreendimento. Com isso, a divisão técnica do trabalho, herdada ou adotada pelo grupo, fica impedida de reproduzir e cristalizar as diferenças de saberes e de competências iniciais, sem redundar em concentração de poder, distinções de mérito e discriminações. Embora em alguns casos tenham ocorrido retrocessos na socialização do conhecimento, em paralelo com um desequilíbrio gradativo na participação dos sócios-trabalhadores, entre 1998 e 2003 a maior parte dos EES bem-sucedidos manteve essa preocupação com iniciativas concretas. A medida mais disseminada refere-se a procedimentos de divulgação e debate das in- 
formações vitais ao empreendimento [A9], da qual não se teve indícios em apenas $22 \%$ dos EES.

No tocante à qualificação da força de trabalho [V13] e a ações mais gerais de educação [V15] ou de cultura e lazer [E4], o desempenho dos indicadores aponta haver flancos, por falta de oportunidades de formação da base social dos empreendimentos, de tempo livre e de investimentos. Há, no entanto, exemplos dignos de nota, como os convênios visando à escolarização básica de todos os seus membros, ou que mantêm assessorias e cursos técnicos para os associados. Algumas cooperativas de trabalho destacam-se pela importância que atribuem à capacitação dos sócios, seja técnica ou doutrinária. Em termos gerais, referendando a importância presumível desse fator para o êxito dos empreendimentos, constata-se que as ações educativas direcionadas aos sócios são nitidamente mais freqüentes (80\%) nos EES mais bem posicionados globalmente, contra $20 \%$ nos EES situados no outro extremo.

A pesquisa não utilizou indicadores para aferir diretamente o grau de socialização interna de saberes. No entanto, pode-se avaliar sua maior ou menor probabilidade, de acordo com a existência de certas práticas afins, como a adoção de processos coletivos de trabalho ou a rotatividade de funções e tarefas. Conforme já apontado, são freqüentes nos EES processos de trabalho executados em grupos, setores etc., particularmente entre aqueles de melhor desempenho, que os empregam amplamente no âmbito da sua principal atividade econômica. Ainda assim, a alternância de tarefas, que poderia engendrar uma circulação de experiências e saberes, não se verifica como prática corrente na maioria dos casos, estando, ao que tudo indica, condicionada pelos formatos produtivos e pelos requisitos de competência indispensáveis a cada função, nos marcos da divisão técnica do trabalho, característica do setor produtivo correspondente. Nesse aspecto, enquanto não se difunde a solidariedade técnica (Lianza e Addor, 2005), necessária à construção e circulação de novos saberes coletivos, os EES menos inovam e mais adaptam-se às circunstâncias.

Os indicadores da pesquisa relacionados a esse tema são mais escassos e exigem a consideração de outros dados de campo. Um traço fundamental, observado em vários empreendimentos, é a sua negativa em reeditar os preconceitos e discriminações que boa parte de seus integrantes sofre em seu cotidiano. Assim, os EES são formados não apenas por trabalhadores pobres ou de modestas economias, mas por pes- 
soas que agregam outras de seus círculos de relações e convivência, parceiros de infortúnio como negros, mulheres e idosos. Às vezes, instituem diretivas intencionalmente destinadas à filiação de portadores de doenças contagiosas, apenados e outras situações estigmatizantes. A economia solidária exemplifica, dessa forma, a observação de que hoje se verificam "mudanças dos mecanismos e das dinâmicas de construção dessas novas identidades sociais como sujeitos coletivos", decorrentes "da pulverização dos espaços de construção da identidade cidadã [...] mas também porque ela vem implicando a reconstrução de novas redes associativas sob novas condições relativas aos preceitos da cidadania, vale dizer, igualdade, justiça e liberdade" (Cohn, 2003:73-75).

\section{UM EMBATE PELA EXISTÊNCIA SOCIAL}

Nos limites do seu campo de ação, mas de forma efetiva, os EES incidem sobre uma série de divisões imperantes na sociedade, quebrando elos de reprodução das desigualdades. Geralmente, eles nascem de objetivos despretensiosos quanto a provocar reviravoltas no padrão de vida dos indivíduos ou a propugnar por amplas mudanças sociais. Respondem, em primeiro lugar, a necessidades de proteção e de vida digna. Aumentam suas chances de êxito quando logram amoldar-se aos arranjos individuais, familiares e semicoletivos conhecidos dos trabalhadores, já inseridos na experiência deles e nos seus círculos de relação e influência. Cumprem, então, o papel de potencializar tais arranjos, à medida que reorganizam os seus fatores produtivos, materiais e humanos.

A esse respeito, vale mencionar o estudo de Magalhães e Abramovay (2005) sobre experiências no Estado da Bahia: a progressiva formação de uma ampla rede de cooperação e, a seguir, de um sistema de cooperativas de crédito direcionadas a pequenos agricultores familiares do sertão baiano, propiciou seu acesso ao mercado financeiro, novos canais de comercialização, organização de sua vida econômica e melhor administração do dinheiro. Essa modernização econômica do sertanejo, liberando-o dos vínculos personalistas e expropriatórios com os agentes econômicos convencionais, teve por fundamento os valores comunitários e religiosos daquela população, vindo a produzir um sistema de mercado alternativo, profissional na gestão dos negócios e, ao mesmo tempo, dotado de uma lógica social irredutível ao registro utili- 
tarista, pois assente em princípios éticos e no compromisso de suas instituições com um projeto social para a região.

No contexto urbano, efeitos do igualitarismo em cooperativas criadas a partir da conversão de empresas capitalistas, anteriormente estruturadas sobre a divisão técnica e social do trabalho, encontram-se em estudos como os de Esteves (2004) e Novaes (2005). No primeiro caso, uma cooperativa industrial paulista, uma vez superada a fase inicial de negociações e ajustes, operou uma aproximação das faixas salariais, com elevação do piso e diminuição do teto da folha de pagamentos, em uma clara política de transferência interna de renda, adotando, em seguida, os dissídios coletivos como parâmetros mínimos de reajuste e instituindo um plano de benefícios e promoções. Essas medidas não comprometeram as contas da empresa. O segundo estudo lança uma análise comparativa de empresas autogestionárias na Argentina e no Uruguai. Uma das inovações refere-se à repartição igualitária dos vencimentos dos sócios-trabalhadores. $\mathrm{O}$ fato de trabalhadores gerirem uma fábrica é digno de registro: aqueles que

"não tinham uma vaga intuição dos aspectos relacionados à administração agora podem debater problemas relacionados à comercialização do produto, planos de investimento, maior liberdade para discutir aspectos relacionados à inovação em produtos, processos, adaptação e fertilização do antigo maquinário em componentes novos" (Novaes, 2005:106).

As fábricas recuperadas "vêm permitindo tanto a manutenção quanto a ampliação do conhecimento dos trabalhadores, na medida em que muitos trabalhadores que antes não dialogavam ou viam no outro uma espécie de ameaça ao seu trabalho, agora são obrigados a enfrentar uma situação extremamente nova" (ibidem).

O segmento das cooperativas populares de trabalho, posto em meio ao fogo cruzado entre os artifícios patronais de barateamento da força de trabalho e a busca pelos trabalhadores de opções de renda, evidencia igualmente possibilidades de promover benefícios importantes, como as retiradas mensais garantidas, o sentimento de aceitação social e o orgulho de pertencer a uma comunidade. Um estudo de três experiências na baixada paulista conclui que

"se a economia não oferece oportunidade legal para a sobrevivência de pessoas que estão em condições de desigualdade social, elas encontra- 
ram no cooperativismo uma forma de viver com solidariedade, potencializando ações de pessoas simples em empreendimentos com objetivos econômicos, resgatando a cidadania e promovendo o desenvolvimento regional" (Vieira, 2005:112).

A depender de sua força instituinte, a economia solidária poderá dotar-se de um marco específico que reconheça e sustente o fundamento associativo de suas organizações e o seu caráter ao mesmo tempo econômico e social ${ }^{17}$. Por hora, importa reconhecer que seus ganhos modestos são valiosos porque derivam da preservação, da revitalização ou da introdução de formas de produção da vida não-capitalistas. Tais formas são fundamentais para a vida dos pobres e para os indivíduos que vivem do seu trabalho, por terem a virtude de abrandar a sujeição destes à economia dominante e de conjurar o exclusivismo das relações de subordinação e expropriação.

Mas não só: como salienta Calvino (1990), os desventurados crescem em número, mas curiosamente ficam expostos à invisibilidade. Ao serem percebidos unicamente nas suas carências, os pobres deixam de existir nos circuitos de legitimação social e de reconhecimento não inferiorizante na esfera pública ${ }^{18}$. O valor talvez mais fundamental dos experimentos de economia solidária reside na mudança e no bem que acarretam para seus próprios protagonistas, ao escaparem da lógica dominante de classificação social. Eles criam sujeitos de suas relações econômicas e de seus vínculos sociais, colocam (mais uma vez) novos atores em cena, em favor de um presente mais digno e inclusivo, aumentam as possibilidades de um futuro melhor. Esses sinais, pequenos mas de energias vivas e combatentes, compõem uma parcela da base social necessária para sustentar pressões favoráveis a um novo sistema de regulação e de instituição social da economia.

(Recebido para publicação em abril 2007)

(Versão definitiva em setembro 2007) 


\section{NOTAS}

1. Nossa conceituação da economia solidária foi apresentada em artigo anterior da revista DADOS (Gaiger, 2004b) e ficará plasmada ao longo do texto. Uma análise em pormenores da gênese e das dinâmicas que presidem o funcionamento dos empreendimentos de economia solidária encontra-se em Gaiger (2004a; 2006; 2007). Para uma análise internacional comparada, ver Santos (2002).

2. Medidas vigorosas de expansão de direitos em resposta a tais pressões, como a integração dos trabalhadores rurais e de outros setores ao sistema previdenciário, chocaram-se com a erosão incontrolável das economias dos beneficiários e com o alastramento da informalidade, de modo que, ao cabo das últimas décadas, às antigas situações de exclusão social somaram-se novos processos de concentração de renda e de pauperização.

3. A esse respeito, inexiste discriminação contra mulheres e não-brancos quando se trata de empregos pouco valorizados, sendo a mesma evidente na disputa pelas posições mais prestigiadas e bem pagas (Singer, 1999:101).

4. No caso do Rio Grande do Sul, os dados da Pesquisa Nacional por Amostra de Domicílios - PNAD de 2002 indicam que a pobreza, mensurada pela renda, abrange mais as mulheres, os negros, os pardos e os jovens (Picolotto, 2005). Conclusões similares valem para o Brasil: embora os atributos pessoais não produtivos sejam um fator complementar das desigualdades de rendimentos, em relação àqueles provenientes do trabalho, na média os maiores rendimentos do trabalho são pagos a homens brancos, bem educados, residindo no Sudeste (Medeiros, 2005:261).

5. "Apenas com a repetição, por duas vezes consecutivas, do 'milagre econômico' da década de 1970, sem, porém, o aumento da concentração de renda que o acompanhou, é que o crescimento seria capaz de levar a incidência da pobreza para abaixo de um terço dos níveis atuais" (Medeiros, 2005:250).

6. Fato que motivou o seu primeiro mapeamento nacional, promovido pela Secretaria Nacional de Economia Solidária, vinculada ao Ministério do Trabalho e Emprego MTE entre 2005 e 2007. A maioria absoluta dos 15 mil empreendimentos registrados em 2006 é dirigida coletivamente por seus sócios-trabalhadores.

7. Uma pesquisa intermediária agregou mais 17 casos aos 30 originais, dos quais 32 foram reexaminados em 2003, 28 deles já estudados em 1998 (dois empreendimentos desse ano, de êxito a rigor discutível à época, foram desativados; um empreendimento dividiu-se em três novos, especializando suas atividades).

8. Por se tratarem de indicadores não dedutíveis de características naturais diretamente observáveis dos empreendimentos, sua apresentação completa ao leitor seria longa e improdutiva para os fins deste artigo. Aqueles utilizados adiante terão o seu sentido oportunamente esclarecido.

9. A distinção entre o atendimento pleno ou parcial do indicador depende de critérios auxiliares, relacionados à natureza do indicador e aos tipos de empreendimento.

10. Utilizaremos a sigla EES para empreendimentos econômicos solidários, referindo-nos às 32 experiências pesquisadas. Os EES de triagem de resíduos sólidos são mais conhecidos como empreendimentos de reciclagem.

11. Os indicadores figuram em cada tabela segundo a ordem de exposição do texto. À esquerda, o percentual de EES que os evidenciam (de modo pleno ou parcial, soma- 
dos); à direita, a classificação dos indicadores, entre os 60 utilizados na pesquisa, sinalizam o seu grau de disseminação entre os empreendimentos.

12. A análise é feita mediante comparação entre o perfil dos 10 EES de melhor desempenho global e os 10 de menor desempenho. Para exemplificar, os indicadores A12, A11 e A10 contabilizam escores superiores a $80 \%$ no primeiro grupo contra pontuações modestas no segundo.

13. Um dado a salientar, visto que as diferenças de remuneração nos níveis inter e intra-ocupacionais são o que melhor explica as desigualdades entre ricos e não-ricos no Brasil, a renda agregada das famílias não-ricas estando ainda mais dependente do trabalho (Medeiros, 2005:261).

14. O que não as dispensa, por certo. O cálculo da renda monetária dos sócios exigiria equacionar um conjunto de variáveis, respeitando as formas de organização da atividade econômica e mensurando-a no nível dos indivíduos e da contribuição de tais rendimentos para a composição de suas rendas familiares, unidade mais confiável para efeitos comparativos (Medeiros, 2005; Neri, 2007). A falta de evidências de que os EES estariam promovendo mudanças significativas nesse plano, somada ao óbice de que a unidade de pesquisa foram as organizações, não os indivíduos e suas famílias, prejudicou as estimativas dessa ordem em pelos menos $28 \%$ dos casos.

15. O compromisso de manter as pessoas ocupadas cria restrições e obriga o EES a descartar alternativas que seriam normais em empresas privadas, como dispensar trabalhadores ou utilizar padrões de remuneração muito diferenciados. Desse ponto de vista, a instabilidade de pessoal dos EES diferencia-se da insegurança reinante no mercado formal de trabalho e nas ocupações informais, sorte a que de outro modo estariam sujeitos os empreendedores solidários e com a qual se comparam, na hora de sopesar as vantagens e inconvenientes dessas alternativas.

16. Dos EES pesquisados, lançaram-se, em vários casos, com sucesso dirigentes de sindicatos, presidentes de associações e candidaturas políticas.

17. O marco legal da economia solidária tem ensejado intensa discussão nos últimos anos e ganhou novo vigor no âmbito do recém-instalado Conselho Nacional de Economia Solidária.

18. Fato brilhantemente retratado em Crianças Invisíveis, reunião de sete curtas-metragens dirigidos por Kátia Lund, Spike Lee, Ridley Scott e outros. 


\section{REFERÊNCIAS BIBLIOGRÁFICAS}

ASSEBURG, Hans Benno. (2007), Análise do Perfil e do Potencial dos Empreendimentos Econômicos Solidários no Rio Grande do Sul para Gerar Empregos e Diminuir os Níveis de Pobreza. Relatório para o Small Grants Programme da Unesco. São Leopoldo, Unisinos.

BARROS, Ricardo et alii. (2007), “A Importância da Queda Recente da Desigualdade para a Pobreza", in R. Barros, M. Foguel e G. Ulyssea (orgs.), Desigualdade de Renda no Brasil: Uma Análise da Queda Recente. Rio de Janeiro, IPEA, pp. 331-353.

BRUYNE, Paul, HERMAN, Jacques e SCHOUTHEETE, Marc. (1974), Dynamique de la Recherche en Sciences Sociales. Paris, Presses Universitaire de France.

CALVINO, Italo. (1990), As Cidades Invisíveis. São Paulo, Companhia das Letras.

COHN, Amélia. (2003), “Reconfigurações da Questão Social no Brasil”. Disponível em http:/ / www.socialwatch.org/en/informeImpreso/pdfs / panorbrasileirod2003 bra.pdf, acessado em 27/4/2006, pp. 71-76.

CORAGGIO, José Luis. (1999), Política Social y Economía del Trabajo; Alternativas a la Política Neoliberal para la Ciudad. Madrid, Miño y Dávila Editores.

DEDECCA, Cláudio. (2007), “A Redução da Desigualdade no Brasil: Uma Estratégia Complexa", in R. Barros, M. Foguel e G. Ulyssea (orgs.), Desigualdade de Renda no Brasil: Uma Análise da Queda Recente. Rio de Janeiro, IPEA, pp. 299-330.

DEJOURS, Christophe. (2007), A Banalização da Injustiça Social (7a ed.). Rio de Janeiro, Editora FGV.

Departamento Intersindical de Estatística e Estudos Socioeconômicos - DIEESE. (2002), A Situação do Trabalho no Brasil. São Paulo, Dieese.

ESTEVES, Egeu. (2004), Sócio, Trabalhador, Pessoa: Negociações de Entendimentos na Construção Cotidiana da Autogestão de uma Cooperativa Industrial. Dissertação de mestrado em Psicologia, USP, São Paulo.

GADOTTI, Moacir. (1993), "Educação Comunitária e Economia Popular", in M. Gadotti e F. Gutierrez (orgs.), Educação Comunitária e Economia Popular. São Paulo, Cortez, pp. 11-22 (Coleção Questões da Nossa Época, 25).

GAIGER, Luiz Inácio. (2003), "Empreendimentos Econômicos Solidários", in A. D. Cattani (org.), A Outra Economia. Porto Alegre, Veraz, pp. 135-143.

GAIGER, Luiz Inácio (org.). (2004a), Sentidos e Experiências da Economia Solidária no Brasil. Porto Alegre, Editora da UFRGS.

GAIGER, Luiz Inácio. (2004b), “A Economia Solidária e o Projeto de Outra Mundialização". DADOS, vol. 47, no 4, pp. 799-834.

. (2006), "A Racionalidade dos Formatos Produtivos Autogestionários". Revista Sociedade e Estado, vol. 21, no 2, pp. 513-545.

. (2007), "Nouvelles Formes de Production Non Capitaliste au Brésil". Revue Tiers Monde, no 190, pp. 1-16.

et alii. (1999), "A Economia Solidária no RS: Viabilidade e Perspectivas". Cadernos CEDOPE, vol. 10, no 15 (Série Movimentos Sociais e Cultura). 
GAIGER, Luiz Inácio e SCHÜTTZ, Gabriela. (2005), “O Mister de Reapreender os Vínculos entre a Economia e a Vida Social”, in L. Zart (org.), Educação e Sócio-Economia Solidária: Interação Universidade - Movimentos Sociais. Cáceres, Unemat Editora.

KLIKSBERG, Bernardo. (2002), Desigualdade na América Latina: O Debate Adiado (3a ed.). São Paulo/Brasília, Cortez/Unesco.

LIANZA, Sidney e ADDOR, Felipe (orgs.). (2005), Tecnologia e Desenvolvimento Social e Solidário. Porto Alegre, Editora da UFRGS.

MAGALHÃES, Reginaldo e ABRAMOVAY, Ricardo. (2005), A Formação de um Mercado de Microfinanças no Sertão da Bahia. Trabalho apresentado no 29 Encontro Anual da Associação Nacional de Pós-Graduação e Pesquisa em Ciências Sociais - Anpocs, Caxambu, 25-29 de outubro.

MEDEIROS, Marcelo. (2005), O que Faz os Ricos Ricos; O Outro Lado da Desigualdade Brasileira. São Paulo, Hucitec/Anpocs.

NERI, Marcelo. (2007), “A Dinâmica da Distribuição Trabalhista” , in R. Barros, M. Foguel e G. Ulyssea (orgs.), Desigualdade de Renda no Brasil: Uma Análise da Queda Recente. Rio de Janeiro, IPEA, pp. 207-235.

NOVAES, Henrique. (2005), “Quando os Patrões Destroem Máquinas: O Debate em Torno das Forças Produtivas em Fábricas Recuperadas Argentinas e Uruguaias". Revista Ciências Sociais Unisinos, vol. 41, no 2, pp. 100-110.

OLIVEIRA, Ildes. (1988), “Microprojetos Econômicos Comunitários: Limites e Possibilidades". Cadernos do CEAS, no 115, pp. 34-52.

PICOLOTTO, Volnei. (2005), Pobreza como Privação de Capacitações no Rio Grande do Sul. Trabalho apresentado no VIII Encontro de Economia da Região Sul do Brasil ANPEC Sul. Disponível em http://www.ppge.ufrgs.br/anpecsul2005/artigos/ area1-05.pdf, acessado em 15/5/2007.

POCHMANN, Márcio. (2001), A Década dos Mitos. São Paulo, Contexto.

PUTNAM, Robert. (1996), Comunidade e Democracia: A Experiência da Itália Moderna. Rio de Janeiro, Fundação Getulio Vargas Editora.

RODRÍGUEZ, Carlos. (2005), "Sete Grandes Debates sobre Desigualdade Social”, in A. D. Cattani e L. Mota (orgs.), Desigualdades na América Latina; Novas Perspectivas Analíticas. Porto Alegre, Editora da UFRGS, pp. 207-233.

SALES, Teresa. (1994), "Raízes da Desigualdade Social na Cultura Política Brasileira". Revista Brasileira de Ciências Sociais, vol. 25, no 9, pp. 26-37.

SALM, Cláudio. (2007), “Sobre a Recente Queda da Desigualdade de Renda no Brasil: Uma Leitura Crítica", in R. Barros, M. Foguel e G. Ulyssea (orgs.), Desigualdade de Renda no Brasil: uma Análise da Queda Recente. Rio de Janeiro, IPEA, pp. 279-297.

SANTOS, Boaventura de Souza (org.). (2002), Produzir para Viver: Os Caminhos da Produção Não-Capitalista. Rio de Janeiro, Civilização Brasileira.

SEN, Amartya. (1999), L'Économie Est une Science Morale. Paris, La Découverte. (2001), Desigualdade Reexaminada. Rio de Janeiro, Record. 
SCHERER-WARREN, Ilse. (1996), "A Ação Cidadã no Combate à Pobreza”, in L. Gaiger (org.), Formas de Combate e de Resistência à Pobreza. São Leopoldo, Editora Unisinos, pp. 13-22.

SINGER, Paul. (1999), Globalização e Desemprego; Diagnóstico e Alternativas (3a ed.). São Paulo, Contexto.

VIEIRA, Arlete. (2005), Cooperativismo de Trabalho; Alternativa de Geração de Trabalho e Renda. Dissertação de mestrado em Gestão e Desenvolvimento Regional, Universidade de Taubaté, Taubaté.

\section{ABSTRACT \\ The Solidary Economy in face of the Inequalities}

Based on empirical evidences gathered from researches about exemplary experiences in solidary economy, the article discusses the expectations associated to this kind of experiences in face of the question of inequality. In evaluating indicators related to egalitarian principles, it estimates the benefits brought by those undertakings, as well as their limitations when it comes to improve and equalize the life conditions of their participants. Comparing such conclusions with other empirical studies, and considering the debate on the roots of inequalities, the article relates the virtues of the solidary economy to the social protagonism it propitiates to workers, a condition for them to escape from the circles of deprivation, subalternity and disregard reserved to them by the dominant social order.

Key words: self-management; citizenship; solidary economy; poverty; work

\section{RÉSUMÉ}

\section{L'Économie Solidaire face aux Inégalités}

Dans cet article, on discute les espoirs placés dans l'économie solidaire face aux inégalités, à partir de résultats empiriques trouvées dans des recherches sur des expériences modèles de ce genre d'économie. En examinant des indicateurs liés à des principes d'égalité, on évalue les bénéfices apportés par ces actions, ainsi que leurs limites pour améliorer et adapter les conditions de vie de leurs publics. En comparant ces conclusions à celles d'autres études empiriques à propos des racines des inégalités, on met en rapport les vertus de l'économie solidaire et l'action sociale qui permet aux travailleurs d'échapper aux cercles de privation, de subordination et d'oubli que leur réserve l'ordre social dominant.

Mots-clé: autogestion; citoyenneté; économie solidaire; pauvreté; travail 